\title{
MANAGEMENT BOARD'S REPORT ON THE ACTIVITIES AS A TOOL OF CORPORATE GOVERNANCE: THE PERSPECTIVE OF CAPITAL PROVIDERS, SUPERVISORY BOARDS, AND OTHER STAKEHOLDERS
}

\begin{abstract}
This article aims to identify and analyse areas of use of report on the activities as a tool of corporate governance implemented by capital providers, members of supervisory boards, and other stakeholders. The contents presented in this article are based on studies of domestic and foreign literature and an analysis of the annual reports of public companies listed on the Warsaw Stock Exchange. This paper analyses the usage of report on the activities for three categories of users, i.e., capital providers, supervisory boards, and other stakeholders. The report on the activities is to help managers to account for their actions. For capital providers the report on the activities provides information on the use of the invested capital by the management board. In turn, for other stakeholders report on the activities provides information on, e.g., corporate social responsibility. Particularly important seems to be the use of the report on the activities by supervisory boards. Considering that in many companies, supervisory boards are involved in formulation of strategy of the company, the supervision over the report on the activities, which largely contains information which is a derivative of the strategy, takes on a new dimension. The exercise of supervision by supervisory boards over the report on the activities has two main levels. The first consists in checking the correctness of the data disclosed in the report on the activities, and the other in checking the assumptions concerning the future of the company formulated in the report. Considerations in this article concern the two-tier model of supervision applicable, among others, in Poland.

Keywords: report on the activities, corporate governance, supervisory board, capital providers.
\end{abstract}

\section{INTRODUCTION}

Along with changes in economic realities also the tools which companies communicate with their environment are changing. In the case of publicly listed companies the key role is played by two communication tools of different character, i.e., the financial statements and the report on the activities. The financial statements contain financial information, in turn; the report on the activities next to financial information contains primarily

\footnotetext{
${ }^{1}$ Jacek Gad, PhD, Department of Accounting, Faculty of Management, University of Lodz, Matejki St. 22/26, 90-237 Lodz, e-mail: jgad@uni.lodz.pl
} 
non-financial information. In addition, the report on the activities is of narrative character. These reports are interrelated - the information contained in the report on the activities is a translation of the information contained in the financial statements into the nonfinancial language.

The status of the report on the activities in the modern system of reporting is increasing. Legislation on the report on the activities is now changing. There is now a separate Polish National Accounting Standard No. 9 Report on the activities. In 2010 an important international standard on the report on the activities was developed, i.e., IFRS Practice Statement. Management Commentary. A framework for presentation, IASB, 2010. The standard presents the essence of contemporary report on the activities and its relationship with the financial statements.

More attention is also paid to the credibility of the report on the activities. Both the National Accounting Standard, No. 9, as well as Management Commentary suggest that the report on the activities should meet the same quality characteristics as the financial statements. A manifestation of legislative measures to strengthen the credibility of the report on the activities is the implementation of the provisions of the European Parliament and of the Council 2013/34 / EU of 26 June 2013 into the Polish Accounting Act. The amendment to the Polish Accounting Act of July 23, 2015 requires the auditors to:

- indicate whether the information contained in the report on the activities includes the provisions of the Polish Accounting Act and is consistent with the information contained in the annual financial statements;

- make a statement, whether in the light of their knowledge about the entity and its environment obtained during the audit any major distortions were found in report on the activities, and indicate what they consist in;

- indicate whether the issuer which is obliged to make a statement on the use of corporate governance entered relevant information into this statement.

This article aims to identify and analyse areas of the use of the report on the activities as a tool of corporate governance implemented by capital providers, members of supervisory boards, and other stakeholders. These three categories of the report on the activities users differ among others in terms of belonging to a category of priority users of the report on the activities and in terms of the scope of available information from the enterprise information system, including accounting information system ${ }^{2}$.

The following issues concerning report on the activities were presented in the relevant literature: The contents of the report on the activities ${ }^{3}$, changes in national and international legislation for reporting non-financial information ${ }^{4}$, or placement of report on the

2 J. Gad, Atrybuty użytkowników wewnętrznych i zewnętrznych systemu informacyjnego rachunkowościperspektywa asymetrii informacji, "Problemy Zarządzania" 46/2(2014), p. 114-128.

${ }^{3}$ J. Krasodomska, Informacje niefinansowe w sprawozdawczości spółek, Wydawnictwo Uniwersytetu Ekonomicznego w Krakowie, Kraków 2014; J. Krasodomska, Sprawozdawczość zintegrowana jako nowy obszar badań naukowych w rachunkowości, "Zeszyty Teoretyczne Rachunkowości” 138/82(2015).

${ }^{4}$ J. Krasodomska, Komentarz świetle wytycznych Rady Międzynarodowych Standardów Rachunkowości, "Zeszyty Teoretyczne Rachunkowości” 117/61(2011); E.I. Szczepankiewicz, Management Commentary jako no- 
activities in the annual report ${ }^{5}$. The analysis of report on the activities with regard to three categories of users, presented in this article, has not been comprehensively described in the literature.

The article was prepared on the basis of literature studies and analysis of the annual reports of companies listed on the Warsaw Stock Exchange. Considerations apply to the two-tier model of supervision. The economic and legal system in force in Poland is the reference point for the discussion within this article.

\section{THE REPORT ON THE ACTIVITIES IN THE CONTEMPORARY MODEL OF REPORTING}

The scope and name of the report on the activities are different in different jurisdictions. The report may be referred to as Management report, Management's discussion and analysis (MD \& A), and Operating and financial review (OFR). In publicly listed companies it is, next to the financial statements, a component of the financial report. The report on the activities falls within the "other financial reporting" however, that the activity report is not a component of the financial statements, although the information presented therein, due to its descriptive nature, is similar to one of the components of the financial statements, i.e., the notes, but in no way does it replace it. The notes, which are integral, inseparable part of the financial statements, are a direct specification of the balance sheet, profit and loss account, cash flow statement and statement of changes in equity ${ }^{7}$.

While analysing the relationship between the financial statements and the report on the activities it is worth mentioning the two dimensions of the report's usefulness. The first dimension is the usefulness of the report on the activities as a separate component of the company's reporting, and the other comes down to the fact that the information contained in the report on the activities enhances the usability of traditional financial reporting $^{8}$.

As noted in the literature the financial statements do not reflect entirely the economic reality of the entity, which enables the management board to misrepresent or conceal the genuine financial situation of the entity ${ }^{9}$. In addition, as pointed out by D. Tweedie, for-

we źródło informacji o działalności jednostki gospodarczej, "Zeszyty Teoretyczne Rachunkowości” 122/66 (2012); J. Gad, Sprawozdanie z działalności we współczesnym modelu raportowania - praktyka sprawozdawcza spótek publicznych notowanych na GPW, "Zarządzanie i Finanse" 2015/1.

${ }^{5}$ M. Marcinkowska, Raport roczny z działalności i wyników przedsiębiorstwa. Nowe tendencje $w$ sprawozdawczości biznesowej, Kraków 2004; P. Mućko, Atrybuty sprawozdania z działalności na tle sprawozdania finansowego, "Zeszyty Teoretyczne Rachunkowości” 122/66(2012).

${ }^{6}$ Preface to International Financial Reporting Standards, IASB 2002.

${ }^{7}$ J. Gad, Sprawozdanie z działalności..., p. 65.

${ }^{8} \mathrm{~J}$. Gad, Cechy jakościowe informacji zawartych $w$ raporcie biznesowym $w$ świetle potrzeb informacyjnych dawców kapitalu, "Zeszyty Naukowe Uniwersytetu Szczecińskiego. Finanse, Rynki Finansowe, Ubezpieczenia" 62/766 (2013), p. 545.

${ }^{9}$ T. Tinker, The Accountants as Partisan, “Accounting, Organizations and Society" 16/3 (1991), p. 297-310. 
mer chairman of the International Accounting Standards Board (IASB), "accounting doesn't do things too well sometimes and that is why the narrative statement is going to be so important in addition to the raw facts" ${ }^{\prime 10}$. The report on the activities can to some extent eliminate the weaknesses of financial reporting. The report on the activities is particularly valuable for users who do not possess sufficient knowledge of finance and accounting and who alone can examine financial reports with some difficulty ${ }^{11}$. According to D. Tweedie the report on the activities is one of the most interesting parts of the annual report. It enables managers to add context to financial information published by companies and explain their future strategy and objectives ${ }^{12}$. What's more, plans and objectives set out in the report on the activities affect the measurement of items in the financial statements.

Due to the evolution of corporate reporting practice the report on the activities has become a central link between the financial statements and other non-financial reports (concerning, e.g., sustainable development) ${ }^{13}$. It should be emphasized that both the financial statements and the report on the activities should reflect the perspective of capital providers; while other non-financial reports widen the perspective of capital providers by the perspective of other stakeholders (Figure 1).

Fig. 1. Relations between the financial statements, the report on the activities, and other nonfinancial reports

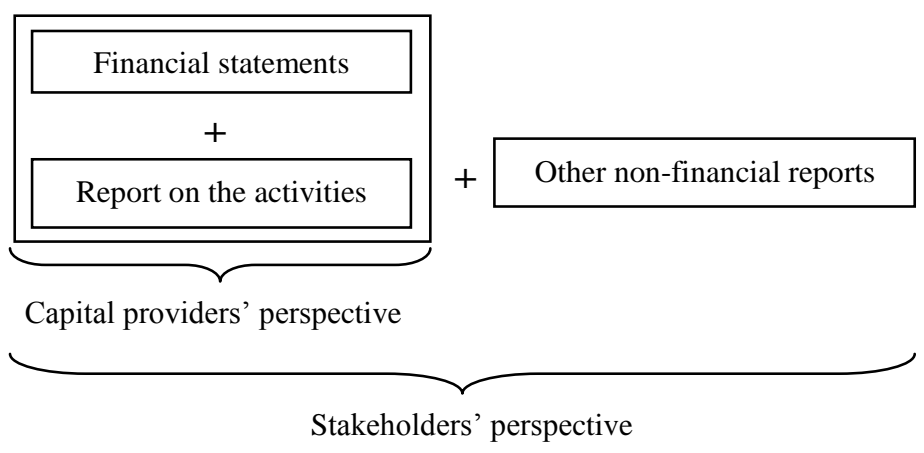

Source: Author's own compilation.

${ }^{10}$ Integrating the business reporting supply chain. A report based on recommendations from key business leaders from around the world, IFAC 2011, p. 29.

${ }^{11}$ M. Marcinkowska, Corporate governance w bankach. Teoria i praktyka, Wydawnictwo Uniwersytetu Lódzkiego, Łódź 2014, p. 325-326.

${ }^{12} \mathrm{Z}$. Zeini, It's not what you think it is. The importance of narrative reporting, "A Middle East Point of View" Deloitte 2011, p. 28.

${ }^{13}$ E. Walińska, J. Gad, Sprawozdanie finansowe jako fundament sprawozdawczości przedsiębiorstwa, [in:] E. Walińska, J. Gad, B. Bek-Gaik, B. Rymkiewicz, Sprawozdawczość przedsiębiorstwa jako narzędzie komunikacji z otoczeniem - wymiar finansowy i niefinansowy, Wydawnictwo Uniwersytetu Łódzkiego, Łódź 2015, p. 56. 
It is often noted that the report on the activity becomes particularly important in terms of disclosure on non-financial indicators e.g., sustainable development or environmental reporting ${ }^{14}$. Thus, it is suggested to extend the report on the activities with perspective of other stakeholders. In practice, there are two main approaches. Under the first approach, next to the report on the activities companies draw up optional non-financial reports which relate directly to the information contained in the report on the activities. According to the second approach companies enrich their report on the activities with additional categories of non-financial information which according to the Author causes confusion.

Presentation of the information in the report on the activities for the needs of a wide group of stakeholders is associated with an expanded concept of corporate governance, according to which corporate governance is a social responsibility born by managers of corporations and is a network of dependencies, not only between the managers of the company and its owners, but also between the company and stakeholders ${ }^{15}$. In the narrow sense of corporate governance the following phenomena are exposed; the separation of ownership from management and the resulting duality of the objectives of managers and shareholders ${ }^{16}$ and the asymmetry of information between these entities.

Both the financial statements and the report on activities are fundamental tools for mitigating information asymmetry accompanying capital markets. Capital providers and other stakeholders do not have access to "internal" information concerning company derived from e.g., management accounting. It should be noted at this point that, as observed by J. Solomon, in the case of institutional investors there may occur a phenomenon of direct corporate governance mechanism involving investors' communication with the management board during individual meetings ${ }^{17}$. There is no doubt, however, that in most cases the reports on the activities are important tools of corporate governance, making it possible to determine whether, and how managers increased (consumed) the capital entrusted by the owners.

Reports on the activities allow capital providers and other stakeholders to control activities of managers - both implemented and planned to be implemented. The report on the activities also seems particularly important from the point of view of the tasks facing the supervisory board (Figure 2).

\footnotetext{
${ }^{14}$ Ibidem, p. 28.

${ }^{15}$ P. Urbanek, Nadzór korporacyjny a wynagrodzenia menedżerów, Wydawnictwo Uniwersytetu Łódzkiego, Łódź 2005, p. 7; J. Solomon, Corporate Governance and Accountability, John Wiley \& Sons Ltd, Chichester 2007, p. 12

${ }^{16}$ P. Urbanek, op. cit., p. 7.

${ }^{17}$ J. Solomon, op. cit., p. 119.
} 
Fig. 2. Report on the activities in an environment of asymmetric information

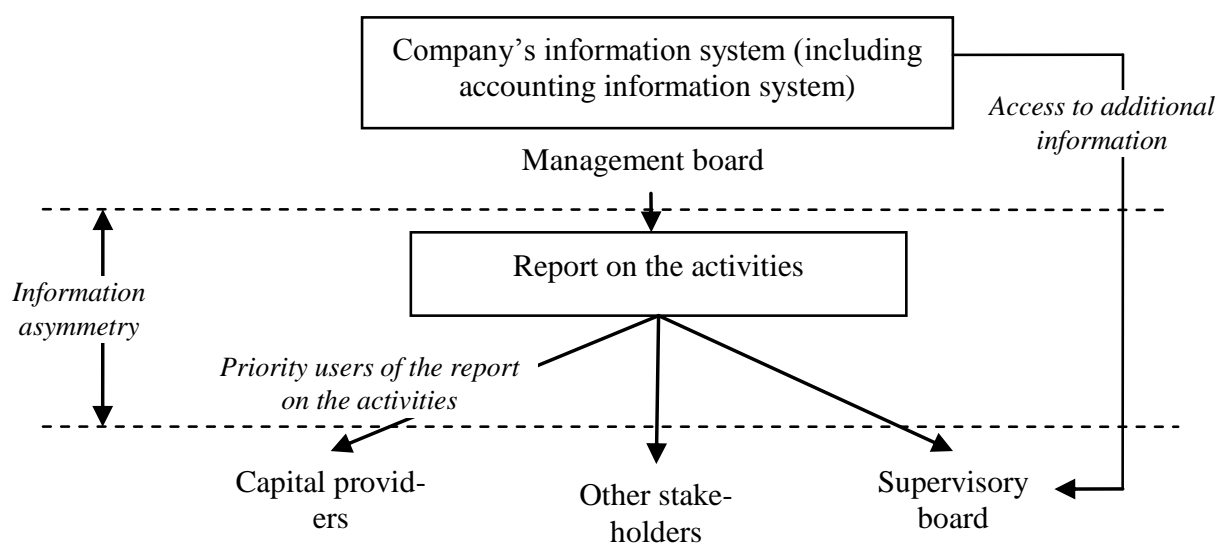

Source: Author's own compilation.

Mitigating the information asymmetry between the management board and the supervisory board and the capital providers is crucial because, as pointed out in the literature, these entities belong to the most important components of the mechanism of control over a publicly listed company ${ }^{18}$.

\section{THE REPORT ON THE ACTIVITIES AS A SOURCE OF INFORMATION FOR CAPITAL PROVIDERS AND OTHER STAKEHOLDERS}

The scope of information disclosed in the report of the activities in the case of public companies listed on the Warsaw Stock Exchange stems from three main sources of regulation: The Accounting Act of 29 September 1994, Journal of Laws No. 76, item 694, as amended, Regulation of the Minister of Finance of 19 February 2009, on current and periodic information submitted by issuers of securities and conditions for recognizing as equivalent the information required by the laws of a non-Member State, Journal of Laws of 2009, No. 33, item 259, the National Accounting Standard No. 9 Report on the activities. The Annex to Resolution No. 6/2014 of Accounting Standards Committee of 15 April 2014.

When preparing the report on the activities one should also take into account an international standard IFRS Practice Statement. Management Commentary. A framework for presentation, IASB, 2010.

\footnotetext{
${ }^{18}$ A. Adamska, Własność i kontrola. Perspektywa akcjonariuszy spótek publicznych, Szkoła Główna Handlowa w Warszawie - Oficyna Wydawnicza, Warszawa 2013, p. 129.
} 
The information content of the report on the activities should, in accordance with the guidelines of the International Accounting Standards Board, be in the first place tailored to the information needs of capital providers. The potential information needs of entities which provide capital to the company should constitute the main premise while preparing the report on the activities.

The report on the activities and financial statements serve as accountability, understood as the fact that the management board accounts for the effectiveness of management of entrusted assets towards owners and other authorized entities ${ }^{19}$. The National Accounting Standard No. 9 states that the report on the activities is to help managers to account for their actions. Importantly, the report on the activities stands out from other nonfinancial reports by fact that it is expected that it will have the same quality characteristics as the financial statements. In addition, as already indicated, the report on the activities and the financial statements take into account in particular the information needs of capital providers.

Publicly listed companies are increasingly presenting information beyond the statutory requirements in their reports on the activity. The strategy of the company is an illustration of such disclosures (Table 1).

Table 1. Excerpt from the strategy of the LW Bogdanka SA

In the years from 2013 to 2020 the company assumes the implementation of the following strategic objectives, to wit:

$\checkmark$ To complete the investment aimed at doubling the production capacity of the mine to approx. 11.5 million tons of commercial coal in 2015.

$\checkmark$ Additional investments in the modernization of the shaft 1.5 in Nadrybie which will allow an increase in net capacity to approx. 12 million tons in 2018.

$\checkmark$ To double resources and lifespan of the mine till approximately 2050 , by obtaining licenses and developing new prospective areas (increase recoverable resources from ca. 237 million tons to ca. 450 million tons).

$\checkmark$ To strengthen the stable position of the main supplier of coal, in particular for power plants - to achieve a $20 \%$ share in sales of thermal coal in the country by 2015 , from ca. $14 \%$ in 2012.

$\checkmark$ To remain the leader in the mining efficiency, reducing at the same time Unit Mining Cash Cost by $15 \%$ by 2017 . in relation to 2012 , in real terms.

$\checkmark$ To maintain the leading position of innovative technical solutions - the implementation of the Intelligent Mine project.

Source: Management Board's Report on the Activities of the Lubelski Węgiel Bogdanka Capital Group for the period from 01 January 2013 to 31 December 2013.

\footnotetext{
${ }^{19}$ A. Jarugowa, Rachunkowość bankowa w warunkach gospodarki rynkowej, [in:] Rachunkowość banków komercyjnych, ed. J. Jarugowa, J. Marcinkowski, M. Marcinkowska, Centrum Edukacji i Rozwoju Biznesu, Warszawa 1994, p. 1.
} 
Information on the strategy seems to be particularly valuable in terms of supervisory process.

The guidelines of the Directive of the European Parliament and of the Council 2014/95/EC of 22 December 2014, which are to be implemented in the legal systems of EU member states by the end of 2016, extend the scope of the report on the activities with information on, e.g., environmental matters, employee-related matters, gender equality, respect for human rights, and the fight against corruption and bribery. The Directive explicitly extends the perspective of the report on the activities from the perspective focused on capital providers on the perspective of stakeholders.

The importance of the report on the activities from the point of view of meeting the information needs of capital providers and other stakeholders has been confirmed empirically. In 2009, the results of studies conducted in Europe were published. The studies concerned expectations of capital providers as to the form and scope of information provided to them by companies ${ }^{20}$. The survey sample consisted of capital providers (lenders, shareholders), analysts, and other users of financial information. ${ }^{21}$

Almost all respondents said that the financial statements and the report on the activities are the most useful sources of financial information. ${ }^{22}$ The survey results indicate that among all reports (including financial statements) presented by companies the report on the activities to the greatest extent provides relevant information from the point of view of decision-making. Almost all respondents answered that they are fully satisfied with regard to the financial information contained in financial reports. The financial information contained in the report on the activities was satisfactory for $72 \%$ of respondents (including $50 \%$ of lenders and $71 \%$ of investors). ${ }^{23}$ Respondents proposed the following improvements in financial and non-financial reporting (1) more / better information about the risk management process, (2) more better quality of prospective financial information, (3) to highlight the trends concerning the growth of the entity and its profitability, (4) more information regarding analysis of competitiveness, (5) to improve information regarding business segments. These improvements in the report on the activities are expected by $48 \%$ of respondents (including $25 \%$ lenders and $67 \%$ investors) ${ }^{24}$.

The results of research conducted in Poland by J. Krasodomska among financial analysts indicate that the report on the activities is the most important source of non-financial information for this professional group. Especially useful for analysts is information re-

${ }^{20}$ The survey was conducted on behalf of two organizations - the Conseil National de la Comptabilité (CNC) and the European Financial Reporting Advisory Group (EFRAG).

${ }^{21}$ The study involved 32 respondents from 10 European countries (including one from Poland).

${ }^{22}$ For $25 \%$ of respondents the press provides useful financial information, for $31 \%$ of respondents important source of information are economic studies, while for $42 \%$ of respondents the information derived from the market.

${ }^{23}$ The respondents from the UK were the exception, they ranked the management commentary (report on the activities) higher than the financial statements.

${ }^{24}$ The needs of users of financial information. A user survey, Pro-Active Accounting Activities in Europe, The Conseil National de la Comptabilité and EFRAG 2009. 
garding the future development of the entity. The results obtained by J. Krasodomska indicate further that the analysts expect a wider range of information than is currently published $^{25}$.

\section{THE SUPERVISORY BOARD TO GUARD THE RELIABILITY OF THE RE- PORT ON THE ACTIVITIES}

Over the last decade, supervisory boards have become an extremely important link in improving the model of disclosures and increasing the reliability of the information disclosed by companies (PwC 2015). In Poland, since 2009, supervisory boards have been required to ensure the reliability of the report on the activities (and the financial statements). This issue is governed by two acts, i.e., the Accounting Act and the Commercial Companies Code.

In accordance with the Accounting Act, the supervisory board is obliged to ensure that the report on the activities (and the financial statements) are in line with the provisions of this Act. ${ }^{26}$ For damage resulting from non-fulfilment of these duties, they are jointly and severally liable towards the company. ${ }^{27}$ Commercial Companies Code, in turn, requires the supervisory boards to evaluate reports on the activities (and the financial statements) with respect to their compliance with the books, documents, and the actual state. ${ }^{28}$

And thus the management board has responsibility for drafting the report on the activities and financial statements, and the supervisory board - through its supervisory activities - ensures their reliability. It seems important to examine what the supervisory activities consist of. This issue is determined by the organization of work of the authorities in the company and by the scope of competence of the same supervisory board.

One should remember that the financial statements are a tool for monitoring the effectiveness of the strategy; hence the information contained therein is a sort of information feedback for supervisory board members. It can therefore be assumed that the supervision over the financial statements is done ex post. In the case of the report on the activities the actions of supervisory boards includes two levels of supervision, i.e., ex post and ex ante. The supervisory board controls the credibility of disclosures on the current financial situation and the achievements of the entity, its changes and the reasons for these changes. It seems that the tasks of the supervisory board should also include the control of the reliability of plans disclosed in the report on the activities (Figure 3).

\footnotetext{
${ }^{25}$ J. Krasodomska, Informacje niefinansowe..., p. 242-244.

${ }^{26}$ Due to the fact that in areas not regulated by the Accounting Act there is a reference to other regulations, for example to the National Accounting Standard No. 9 "Report on the activities" or IFRS it is assumed that the Supervisory Board should ensure conformity of the report on the activities also with these regulations.

${ }^{27} \mathrm{Cf}$. Article 4a of the Accounting Act.

${ }^{28}$ Cf. Article 382, § 3 of the Commercial Companies Code.
} 
Fig. 3. The ex-post and ex-ante supervision

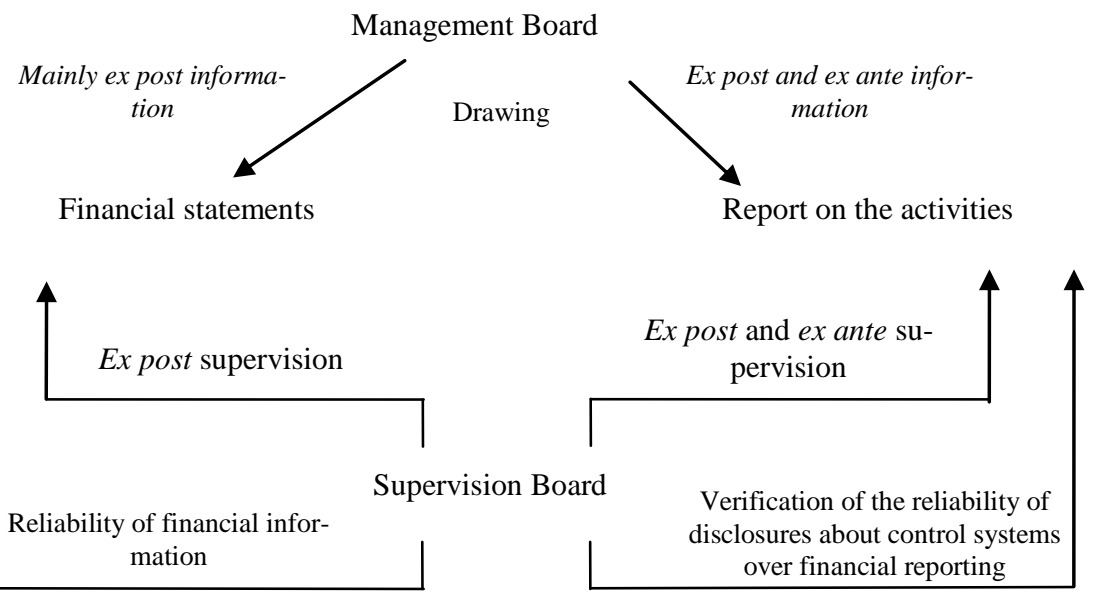

Source: Author's own compilation.

One should keep in mind that the credibility of the financial statements and reports on the activities is determined by the reliability of the entire accounting system. This reliability can be ensured, among others, by expeditious internal control and risk management systems in relation to financial reporting purposes. Disclosures on this subject should be included in the report on the activities. ${ }^{29}$

\section{PARTICIPATION OF SUPERVISORY BOARDS IN FORMULATING COM- PANY PLANS AND STRATEGIES AND SUPERVISION OVER THE RE- PORT ON THE ACTIVITIES}

In today's economic reality supervisory boards not only control the reliability of disclosures on e.g., management board plans, but they themselves shape these plans, which is one of the dimensions of the supervision over the report on the activities. It should be noted that disclosing information concerning future raises some doubts. Firstly, prognostic information is burdened with large uncertainty and secondly, disclosure of information about the company's plans involves the risk of losing competitive advantage ${ }^{30}$.

\footnotetext{
${ }^{29}$ For several years, publicly listed companies have been required to disclose in their reports on the activities the report on the main features of their internal control and risk management systems in relation to financial reporting.

${ }^{30}$ M. Marcinkowska, Raport roczny z działalności i wyników przedsiębiorstwa. Nowe tendencje w sprawozdawczości biznesowej, Oficyna Ekonomiczna, Kraków 2004, p. 138.
} 
According to A. Opalski, "the supervisory board should assist the management board in setting the company's objectives and determining the method of their implementation, therefore, act as institutional advisor and management board's partner. Advisory is a particular manifestation of the supervision and strengthens its effectiveness" ${ }^{\prime 3}$. T. Kulesza aptly notes that the advisory effectiveness of the role of the supervisory board depends, inter alia, on the identification of the supervisory board members with the mission of the company, as well as on the knowledge of the strategy and objectives of the company ${ }^{32}$. It should be noted, however, that "the main task of the supervisory board is not to propose and develop the strategy, but to shape it by assessing and giving opinions on the appropriateness of the management board's guidelines. This assessment should not take precedence over the management board's position"33.

It is also important that the areas of activities of the two bodies do not overlap. It seems that the supervisory board could act as a "visionary of the long-term strategy of the company." In this way the supervisory board members would control the strategic areas of actions of the entity, actively participating in them (at the same time overseeing operating activities). The essence of this model would consist in the fact that the supervisory board together with the management board would create a long-term framework for the operation of the enterprise within which the management board would carry out day-today management of the company. In this way the potential of both corporate bodies would be best used ${ }^{34}$.

The participation of members of the supervisory board in strategic management takes on new meaning at a time when this management area ceased to be merely a theoretical concept, but has become the constant component of business management.

The involvement of supervisory boards in formulating the company's strategy has been confirmed by provisions of reports on the activities of supervisory boards (which are part of the management board's report on the activities) (Table 2). More than 66\% of companies within the Warsaw Stock Exchange WIG 30 index presented in their supervisory boards' reports the activities related to strategic management. Importantly, 30\% of publicly listed companies within the WIG 30 have supervisory board committees on strategy. ${ }^{35}$

\footnotetext{
${ }^{31}$ A. Opalski, Prawo gospodarcze i handlowe. Rada nadzorcza w spótce akcyjnej, C.H. Beck, Warszawa 2006, p. 512.

${ }^{32}$ T. Kulesza, Nadzór korporacyjny a zarządzanie spótka kapitałowa, LexisNexis, Warszawa 2002, p. 202.

${ }^{33}$ A. Opalski, Rada nadzorcza jako strategiczne ogniwo ladu korporacyjnego spótki akcyjnej, [in:] Europejskie prawo spótek, vol. III: Corporate governance, ed. M. Cejmer, J. Napierała, T. Sójka, Wolters Kluwer, Kraków 2006, p. 344-345.

${ }^{34} \mathrm{~J}$. Gad, Rachunkowość w procesie nadzoru w spótkach publicznych, praca doktorska przygotowana pod kierunkiem E. Walińskiej, Łódź 2010, p. 235.

${ }^{35}$ PGE, Tauron, Netia, Orange Polska, TVN, Orlen, Lotos, KGHM, Lubelski Węgiel Bogdanka.
} 
Table 2. Excerpts from supervisory board reports on the activities in companies listed on the Warsaw Stock Exchange (2013).

\begin{tabular}{|c|c|}
\hline $\begin{array}{l}\text { Company } \\
\text { name }\end{array}$ & $\begin{array}{l}\text { The actions of supervisory boards related to the strategic management proc- } \\
\text { ess. }\end{array}$ \\
\hline Alior & $\begin{array}{l}\text { Giving opinions on the Bank's long-term development programmes and annual } \\
\text { financial plans. Approval of the Bank's strategy and the rules of prudent and stable } \\
\text { management of the Bank. }\end{array}$ \\
\hline $\begin{array}{l}\text { City Hand- } \\
\text { lowy Bank }\end{array}$ & $\begin{array}{l}\text { Approval of the Bank's strategy and the rules of prudent and stable management of } \\
\text { the Bank. }\end{array}$ \\
\hline Boryszew & $\begin{array}{l}\text { Measures to improve the efficiency of management of the Company to maximize } \\
\text { the financial performance of the Company and increase its stock market value and } \\
\text { ensure its long-term development. The duties of the Supervisory Board include, } \\
\text { among others, approval of annual action plans of the Company and its long-term } \\
\text { development programs. }\end{array}$ \\
\hline $\begin{array}{l}\text { Cyfrowy } \\
\text { Polsat }\end{array}$ & $\begin{array}{l}\text { Approval of annual and long-term programs of the Company prepared by the } \\
\text { Management Board. }\end{array}$ \\
\hline $\begin{array}{l}\text { ING Bank } \\
\text { Śląski }\end{array}$ & $\begin{array}{l}\text { Approval of the rules of prudent and stable management of the Bank and strategy } \\
\text { prepared by the Management Board and periodic review and verification of its } \\
\text { implementation, as well as the approval of long-term development plans of the } \\
\text { Bank prepared by the Management Board and annual financial plans of the Bank's } \\
\text { operations. }\end{array}$ \\
\hline JSW & $\begin{array}{l}\text { Approval of operational strategies of the JSW SA. Opinions on the annual plans of } \\
\text { the JSW SA. }\end{array}$ \\
\hline KGHM & $\begin{array}{l}\text { Monitoring the implementation by the Management Board's the company's strat- } \\
\text { egy and giving opinions on how the strategy in force meets the needs of the chang- } \\
\text { ing reality. Monitoring the implementation by the Management Board of the an- } \\
\text { nual and multi-year plans of operation of the Company and assessment whether } \\
\text { they require modification. Assessment of the consistency between the annual and } \\
\text { long-term action plans of the company and the strategy of the Company imple- } \\
\text { mented by the Management Board and presenting proposals for possible changes } \\
\text { in all these documents of the company. }\end{array}$ \\
\hline LOTOS & $\begin{array}{l}\text { Determining the scope, detail and deadlines for submission by the Management } \\
\text { Board of annual budgets and multi-annual strategies. Approval of the Group's } \\
\text { strategy. Giving opinions on annual budgets. }\end{array}$ \\
\hline $\begin{array}{l}\text { Lubelski } \\
\text { Węgiel } \\
\text { Bogdanka }\end{array}$ & $\begin{array}{l}\text { Approval of the strategic long-term plans of the Company and their changes. Ap- } \\
\text { proval of annual business and financial plans of the Company and their changes. }\end{array}$ \\
\hline $\mathrm{mBank}$ & Approval of the annual financial plans and long-term development plans. \\
\hline NETIA & $\begin{array}{l}\text { Activities concerning the Company's future development areas. Monitoring key } \\
\text { indicators of investment spending. }\end{array}$ \\
\hline $\begin{array}{l}\text { ORANGE } \\
\text { POLSKA }\end{array}$ & $\begin{array}{l}\text { Examination of the strategic plan and annual budget. Formulation of opinions and } \\
\text { recommendations by the committee on strategy for the Supervisory Board con- } \\
\text { cerning strategic plans prepared by the Management Board and comments from the } \\
\text { Supervisory Board on such plans, in particular concerning the main strategic op- } \\
\text { tions. Consulting all strategic projects. }\end{array}$ \\
\hline ORLEN & $\begin{array}{l}\text { Opinions on the annual financial plans. Approval of the Company's strategy and } \\
\text { long-term financial plans. Evaluation of the impact of planned and implemented } \\
\text { investments and divestments on the shape of the Company's assets. Giving opin- } \\
\text { ions on the development strategy of the Company, including long-term financial } \\
\text { plans. }\end{array}$ \\
\hline
\end{tabular}




\begin{tabular}{|l|l|}
\hline $\begin{array}{l}\text { Company } \\
\text { name }\end{array}$ & $\begin{array}{l}\text { The actions of supervisory boards related to the strategic management proc- } \\
\text { ess. }\end{array}$ \\
\hline PGE & $\begin{array}{l}\text { Approval of annual and long-term financial plans, as well as defining their scope } \\
\text { and when the plans should be submitted by the Board. Approval of the Company's } \\
\text { development strategy. }\end{array}$ \\
\hline PGNiG & $\begin{array}{l}\text { Approval of annual business plans. Approval of the Company's Strategy and the } \\
\text { PGNiG Capital Group and strategic long-term plans. }\end{array}$ \\
\hline $\begin{array}{l}\text { PKO Bank } \\
\text { Polski }\end{array}$ & Approval of the strategy of the PKO Bank Polski SA and the annual financial plan. \\
\hline PZU & $\begin{array}{l}\text { Approval of long-term plans of development of the company prepared by the } \\
\text { Management Board and annual financial plans. }\end{array}$ \\
\hline SYNTHOS & $\begin{array}{l}\text { Approval of annual business plans, financial and marketing plans of the Company } \\
\text { the budget) prepared by the Management Board and detailed reports on their } \\
\text { implementation. }\end{array}$ \\
\hline TAURON & $\begin{array}{l}\text { Evaluation of Corporate Strategy. Evaluation of the impact of planned and imple- } \\
\text { mented strategic investments on the shape the Company's assets. Monitoring the } \\
\text { implementation of strategic investment projects. }\end{array}$ \\
\hline TVN & $\begin{array}{l}\text { Overview of the Business Plan of the TVN Group, monitoring progress in imple- } \\
\text { mentation of the Plan by the TVN Group and its members, in accordance with the } \\
\text { principles and objectives set out in each relevant Business Plan, as well as an over- } \\
\text { view of the conditions of each contemplated acquisition, sale, implementation of } \\
\text { strategic projects, alliances, and cooperation. }\end{array}$ \\
\hline
\end{tabular}

Source: Author's own compilation.

Reports on the activities of supervisory boards indicate that they act as opinionforming as regards the company's strategy. With regard to the involvement of supervisory boards in formulating strategies the reports demonstrate such wordings as: approval, evaluation, review, giving opinions, monitoring, examining, and consulting.

It seems that the model of cooperation between the supervisory board and management board presented in this paper in respect of the strategy works in the practice of public companies.

\section{CONCLUSIONS}

The report on the activities is an important tool of corporate governance. It constitutes one of the main sources of information for shareholders and other stakeholders. The report on the activities presents information which is to help the Management Board to account for its actions. In this report, the management board reveals information about events, decisions and factors which may have a significant impact on the future of the entity; in particular, it is important to determine the entity's objectives and the risks and threats to their implementation. It also provides information on the effectiveness of the use of capital by the Management Board and on the plans related to the use of this capital. The process of enlarging reports on the activities with additional disclosures on e.g., corporate social responsibility makes this report an important source of information for a wide range of stakeholders. The report on the activities also allows shareholders and other stakeholders to better understand the financial statements. 
The report on the activities seems to play a special role in the supervision carried out by supervisory boards. The report is an expression of a consensus obtained between the Supervisory Board and the Management Board regarding e.g., the strategy of the entity. As noted by A. Opalski "the history of supervisory board is a history of breaking by the legislator the original model of integrating managerial functions and supervisory functions in one body. In recent years, however an opposite trend can be observed aimed at ensuring closer cooperation between the supervisory board and the management board. The supervisory board is to be an advisor and management board's partner, and wider participation in shaping the company's strategy is to make supervision more effective." 36

Importantly, while controlling the content of the report on the activities the supervisory board executes both an ex post and ex ante supervision. It checks the compliance of disclosures both with the actual financial situation and assesses the reality of plans and intentions mentioned in the report.

It should be noted that the report on the activities involves certain risk. Due to its form it is difficult to guarantee that all information contained therein will be consistent with reality. The management may be tempted to expose the positive side of the company's operations in the activity report and ignore or present the risks and hazards associated with these activities to a limited extent. In addition, the report provides prognostic data that are difficult to verify. It seems that committing the statutory auditors to assess the conformity of the information contained in the report on the activities with the actual situation of the company, coupled with the control exercised by the supervisory boards will increase its credibility.

\section{REFERENCES}

[1] Adamska A., Własność i kontrola. Perspektywa akcjonariuszy spółek publicznych, Szkoła Główna Handlowa w Warszawie - Oficyna Wydawnicza, Warszawa 2013.

[2] Directive of the European Parliament and of the Council 2013/34/EU of 26 June 2013 on the annual financial statements, consolidated financial statements and related reports of certain types of undertakings, amending Directive of the European Parliament and of the Council 2006/43/EC and repealing Council Directive 78/660/EEC and 83/349/EEC (EU OJ L 182, 29.06.2013).

[3] Gad J., Rachunkowość w procesie nadzoru w spółkach publicznych, praca doktorska przygotowana pod kierunkiem E. Walińskiej, Łódź 2010.

[4] Gad J., Cechy jakościowe informacji zawartych $w$ raporcie biznesowym $w$ świetle potrzeb informacyjnych dawców kapitalu, "Zeszyty Naukowe Uniwersytetu Szczecińskiego. Finanse, Rynki Finansowe, Ubezpieczenia” 62/766 (2013), p. 545-556.

[5] Gad J., Atrybuty użtkowników wewnętrznych $i$ zewnętrznych systemu informacyjnego rachunkowości-perspektywa asymetrii informacji, "Problemy Zarządzania" 46/2(2014): 114128 ,

[6] Gad J., Sprawozdanie z działalności we wspótczesnym modelu raportowania - praktyka sprawozdawcza spótek publicznych notowanych na GPW, "Zarządzanie i Finanse" 2015/1, p. 79-90.

\footnotetext{
${ }^{36}$ A. Opalski, Prawo gospodarcze i handlowe. Rada nadzorcza w spótce akcyjnej, op. cit., p. 34.
} 
[7] IFRS Practice Statement, Management Commentary. A framework for presentation, IASB, London 2010.

[8] Integrating the business reporting supply chain. A report based on recommendations from key business leaders from around the world, IFAC, New York 2011.

[9] Jarugowa A., Rachunkowość bankowa $w$ warunkach gospodarki rynkowej, [in:] Rachunkowość banków komercyjnych, ed. A. Jarugowa, J. Marcinkowski, M. Marcinkowska, Centrum Edukacji i Rozwoju Biznesu, Warszawa 1994, p. 7-33.:

[10] Krajowy Standard Rachunkowości nr 9 Sprawozdanie z działalności, 2014. Załącznik do uchwały Nr 6/2014 Komitetu Standardów Rachunkowości.

[11] Krasodomska J., Komentarz zarzadu w świetle wytycznych Rady Międzynarodowych Standardów Rachunkowości, "Zeszyty Teoretyczne Rachunkowości” 117/61(2011), p. 89-106.

[12] Krasodomska J., Informacje niefinansowe w sprawozdawczości spółek, Wydawnictwo Uniwersytetu Ekonomicznego w Krakowie, Kraków 2014.

[13] Krasodomska J., Sprawozdawczość zintegrowana jako nowy obszar badań naukowych w rachunkowości, "Zeszyty Teoretyczne Rachunkowości” 138/82 (2015), p. 77-92.

[14] Kulesza T., Nadzór korporacyjny a zarzadzanie spótka kapitałowa, Wydawnictwo Prawnicze LexisNexis, Warszawa 2002.

[15] Marcinkowska M., Raport roczny z działalności i wyników przedsiębiorstwa. Nowe tendencje w sprawozdawczości biznesowej, Oficyna Ekonomiczna, Kraków 2004.

[16] Marcinkowska M., Corporate governance w bankach. Teoria i praktyka, Wydawnictwo Uniwersytetu Łódzkiego, Łódź 2014.

[17] Mućko P., Atrybuty sprawozdania z działalności na tle sprawozdania finansowego, "Zeszyty Teoretyczne Rachunkowości” 122/66(2012): 143-152.

[18] Opalski A., Prawo gospodarcze $i$ handlowe. Rada nadzorcza w spótce akcyjnej, C.H. Beck, Warszawa 2006.

[19] Opalski A., Rada nadzorcza jako strategiczne ogniwo ładu korporacyjnego spółki akcyjnej, [in:] Europejskie prawo spótek, vol. III: Corporate governance, ed. M. Cejmer, J. Napierała, T. Sójka, Wolters Kluwer, Kraków 2006.

[20] Preface to International Financial Reporting Standards, IASB, April 2002.

[21] Rady nadzorcze 2015. Trendy i kierunki zmian, PwC 2015.

[22] Solomon J., Corporate Governance and Accountability, John Wiley \& Sons Ltd., Chichester 2007.

[23] Szczepankiewicz E., Management Commentary jako nowe źródto informacji o działalności jednostki gospodarczej, "Zeszyty Teoretyczne Rachunkowości” 122/66 (2012), p. 191-203.

[24] The Act of 15 September 2000 Commercial Companies Code, "Journal of Laws" 2000, No. 94, Item 1037, as amended.

[25] The Act of 23 July 2015 amending the Act on accounting and certain other acts, "Journal of Laws" 2015, Item 1333.

[26] The Act of 29 September 1994 on accounting, "Journal of Laws" 1994, No. 76, Item 694, as amended.

[27] The needs of users of financial information. A user survey, Pro-Active Accounting Activities in Europe, The Conseil National de la Comptabilité and EFRAG, 2009.

[28] Tinker T., The Accountants as Partisan, "Accounting, Organizations and Society" 16/3 (1991), p. 297-310.

[29] Urbanek P., Nadzór korporacyjny a wynagrodzenia menedżerów, Wydawnictwo Uniwersytetu Łódzkiego, Łódź 2005. 
[30] Walińska E., Gad J., Bek-Gaik B., Rymkiewicz B., Sprawozdawczość przedsiębiorstwa jako narzędzie komunikacji z otoczeniem - wymiar finansowy i niefinansowy, Wydawnictwo Uniwersytetu Łódzkiego, Łódź 2015, p. 63-90.

[31] Zahi Z.,It's not what you think it is. The importance of narrative reporting, A Middle East Point of View Deloitte, September 2011, p. 27-29.

\section{SPRAWOZDANIE ZARZĄDU Z DZIALALNOŚCI JAKO NARZĘDZIE NADZORU KORPORACYJNEGO - PERSPEKTYWA DAWCÓW KAPITALU, RAD NADZORCZYCH ORAZ POZOSTAŁYCH INTERESARIUSZY}

Celem artykułu są identyfikacja oraz analiza obszarów wykorzystania sprawozdania z działalności jako narzędzia nadzoru korporacyjnego realizowanego przez dawców kapitału, członków rad nadzorczych oraz pozostałych interesariuszy. Treści zaprezentowane w niniejszym artykule opracowano w oparciu na studiach literatury krajowej i zagranicznej oraz analizie raportów rocznych spółek publicznych notowanych na GPW w Warszawie. W ramach badania wykorzystano metodę indukcji. W niniejszym artykule dokonano analizy wykorzystania sprawozdania z działalności przez trzy grupy użytkowników: dawców kapitału, rady nadzorcze oraz pozostałych interesariuszy. Sprawozdanie z działalności stanowi podstawę do rozliczenia się zarządu z odpowiedzialności. Dawcom kapitału sprawozdanie z działalności dostarcza informacji na temat wykorzystania przez zarząd powierzonego kapitału. Z kolei dla pozostałych interesariuszy sprawozdanie $z$ działalności jest istotne pod względem m.in. społecznej odpowiedzialności przedsiębiorstwa. Szczególnie istotne wydaje się wykorzystanie sprawozdania z działalności przez rady nadzorcze. Biorac pod uwage, że w wielu spółkach rady nadzorcze są zaangażowane $\mathrm{w}$ formułowanie strategii jednostki, nowego wymiaru nabiera nadzór nad sprawozdaniem z działalności, które w dużej mierze zawiera informacje będące pochodną strategii. Sprawowanie przez rady nadzorcze nadzoru nad sprawozdaniem z działalności ma dwie główne płaszczyzny. Pierwsza polega na kontroli prawidłowości ujawnianych danych w sprawozdaniu z działalności, druga natomiast na kontroli założeń dotyczących przyszłości spółki sformułowanych w sprawozdaniu z działalności. Rozważania prowadzone w niniejszym artykule dotyczą dualistycznego modelu nadzoru obowiązującego m.in. w Polsce.

Słowa kluczowe: sprawozdanie z działalności, nadzór korporacyjny, rada nadzorcza, dawcy kapitału

\section{DOI: 10.7862/rz.2016.mmr.5}

Tekst złożono w redakcji: luty 2016

Przyjęto do druku: maj 2016 